\title{
Editor's Note: Is the Multiple Intelligences Theory a Research-Based Theory or a Story with a Positive Message?
}

\author{
Allan Leslie White \\ SEAQiM Yogyakarta
}

\begin{abstract}
Howard Gardner introduced his Theory of Multiple Intelligences in 1983. It is a model of intelligence which differentiates intelligence into various specific (primarily sensory) modalities, rather than being dominated by a single general ability such as IQ. The Theory of Multiple Intelligences has attracted controversy and criticism among the research community but has resonated with teachers and many educationalists who have supported the practical value of various educational approaches suggested by the Theory of Multiple Intelligences. This paper will investigate claims that the Multiple Intelligences Theory is a research-based theory, or as critics have claimed, it is a good story with a positive message.
\end{abstract}

Key Words: Multiple Intelligences, Learning styles, Brain Research

\section{Introduction}

Howard Gardner, the Hobbes Professor of Cognition and Education, coordinator of Project Zero at the Harvard Graduate School of Education and Adjunct Professor of Neurology at the Boston University School of Medicine introduced his Theory of Multiple Intelligences (TMI) in 1983 (Gardner, 1983/1993a). Earlier in 1979, The Bernard Van Leer Foundation had approached Gardner to investigate the human potential.

The invitation led to the founding of Harvard Project Zero, which served as the institutional midwife for the theory of multiple intelligences (Armstrong, 2009, p. 2).

The TMI is a model of intelligence which differentiates intelligence into various specific (primarily sensory) modalities, rather than being dominated by a single general ability such as IQ. Since 1983 there has been considerable discussion of the theory. Gardner originally identified seven distinct intelligences, but later added an eighth 'naturalist' form of intelligence in 1995, and since 1998 has been considering a ninth form of 'existential' intelligence. While some commercial interests quickly adopted the theory to push their own agenda (often with little understanding - see Gardner, 1995) and as a way of generating and selling more resources to teachers, the TMI has attracted controversy and criticism among the research community.

As there another paper in this current edition where multiple intelligence theory is used, it was time to investigate if the Multiple Intelligences Theory is a research-based theory or a story with a positive message. 


\section{Research Evidence for Multiple Intelligence Theory}

In 2004, Emeritous Professor of Philosophy of Education, John White of the London Institute of Education wrote an opinion piece for the Times Educational Supplement titled: Unpick Wooly Thinking; The modish Multiple Intelligence bandwagon is run on flaky, flawed psychology (White, 2004, p. 23). In the same month, he gave a public lecture titled: Howard Gardner-The myth of Multiple Intelligences. He cast serious doubts on the evidence base for Gardner's theory. He was not alone as many cognitive and developmental psychologists argued that there is no empirical evidence to support the theory (Schulte, Ree, \& Carretta, 2004). It is claimed that TMI:

1. lacks precise definitions (Waterhouse, 2006a, 2006b);

2. lacks measurability and has no empirical evidence to back it up (Mathews, 1995; Visser, Ashton, \& Vernon, 2006a, b);

3. violates its assumptions where the eight intelligences did not represent separate and unrelated domains as claimed, but were highly intercorrelated with each other (Furnham, 2009);

4. uses the term intelligences in a way that is simply arbitrary and confusing. Locke (2005) stated that people are capable of developing a variety of different skills, but this does not necessarily mean they require a different kind of intelligence for each one;

5. has produced erroneous conclusions and outcomes such as 'learning styles', which some commercial publishers gleefully used to sell more resources to teachers based on dubious educational claims. There is a great difference between the way that a student says (s)he prefers to learn and the ways that actually leads to better learning (De, Bruyckere, Kirschner, \& Hulshof, 2015). As well, categorizing children and then prescribing something for them based on this categorization is very dangerous, especially when a student is a low-performing student (Stahl, 1999; McEwan-Adkins, 2012);

6. has led to erroneous conclusions and outcomes in the areas of Gifted and Talented and 'personalisation' programs (White, 2004);

7. is so unclear as to be tautologous and thus unfalsifiable. Having a high musical ability means being good at music while at the same time being good at music is explained by having a high musical ability (Klein, 1998);

8. does not discover new "intelligences", but is just a reframing of previously designated cognitive styles (Morgan, 1996);

9. stresses the differences between general intelligence and multiple intelligences, but the two frameworks nevertheless share fundamental characteristics that limit their relevance to teaching. Both identify cognitive structures far too broadly to be useful for interpreting any specific educational tasks (Klein, 1997);

10. does not make a distinction between intelligences and skills (White \& Breen, 1998)

11. does not explain satisfactorily how different intelligences intertwine in real-life applications (Allix, 2000). 
Gardner stayed quiet in the face of the mounting criticism for ten years before responding, stating:

while Multiple Intelligences theory is consistent with much empirical evidence, it has not been subjected to strong experimental tests... Within the area of education, the applications of the theory are currently being examined in many projects. Our hunches will have to be revised many times in light of actual classroom experience (Gardner, 1993b, p. $33)$.

Occasionally, Gardner responded to specific critics, for example:

We have 2 main criticisms: (a) Waterhouse misunderstands and oversimplifies MI theory and (b) Waterhouse's own line of argument undermines her claim that MI theory is not supported by the literature (Gardner \& Moran, 2010).

However, there has not been a comprehensive refutation of the mounting dissatisfaction with TMI which is partly summarised by Allix (2000):

\begin{abstract}
Analysis of Gardner's theory of multiple intelligences uncovers a conception that, in terms of its content and structure, is informed by an outmoded and narrow empiricist theory of knowledge, and associated theory of mind and cognition. As a consequence, the theory fails to furnish methodological resources that are adequate to the tasks of explicating and defending the integrity of its most basic categories, namely the multiple intelligences themselves, and of underwriting the explanatory generalisations that arise therefrom ( $\mathrm{p}$. 286).
\end{abstract}

So, the weight of evidence from research findings appears to be casting doubt upon the theoretical and evidential foundations of TMI but that is not the end of this paper. Having briefly considered the first part of the central question contained in the title of this paper regarding the evidence for TMI, it is time to consider if there are positives for education to be gained from TMI as an inspirational story with a positive message to all teachers, lecturers and educators.

\title{
A Story with a Positive Message?
}

Gardner first arrived at his intuitions concerning the multi-faceted nature of human intelligence from a synthesis of a number of sources of data, especially evidence from neurological, evolutionary, and cross-cultural origins, which had not been considered together before. ... From these new sources of knowledge, Gardner saw the need for a better classification of human capabilities, and description was seen to be an appropriate place to begin this task (Allix, 2000, p. 276).

Why is TMI so popular, and why has it resonated with teachers and many educationalists who have supported the practical value of various approaches suggested by TMI? Even critics such as the earlier mentioned Professor White saw positive messages arising from TMI and was moved to state: 
The idea that intelligence is not tied to IQ but takes many forms has been a liberation... And MI does appear to deliver the goods in terms of inclusion and raising self-esteem... MI also seems good news for pedagogy, as the same topic can be presented differently... (White, 2004, p.23)

TMI has helped to get rid of the days when the grading of students was rigidly implemented according to IQ scores, which have been variously criticised as racist and lacking equity. Rather than limited to the narrow view of IQ scores, TMI promoted the recognition of the multiple skills and talents of students that have boosted acceptance of diversity within classrooms and schools and placed responsibility upon teachers to cater for the individual learning needs of all students.

When Frames of Mind (1983/1993a) was conceived and written in the early 1980s, I viewed myself as a psychologist, attacking the standard notion of intelligence as a single capacity, with which an individual is born, and which proves difficult, if not impossible, to alter. I offered a more pluralistic cognitive universe. (Gardner, 1995, p. 16).

Brain Research has highlighted that children are different through genetic differences but mostly because of their experiences and a teacher must use a variety of approaches within a lesson to cater for all students, both their strengths and their weaknesses, because:

Children are not always stuck with the mental abilities they are born with (Doidge, 2008, p. Xv).

The implications for education are profound, especially for school teaching and learning. It opposes the traditional beliefs that some children are born with certain fixed abilities such as intelligence or the ability to do mathematics.

... scientists now know that any brain differences present at birth are eclipsed by the learning experiences we have from birth onward (Boaler, 2016, p. 5).

In the classroom, teachers have students who are faster than others or who seem to grasp ideas easily. That is because they have had multiple opportunities to make brain connections during their childhood. It is not that students who struggle have less potential, but rather they have not had the opportunities that other students have received. Children are born with the potential to learn and how this potential is nurtured, encouraged, and challenged is the responsibility of parents and teachers.

So, contrary to some misinformed views about students learning styles which advised teachers to categorize all students and then concentrate only upon the dominant style for each student, Gardner proposes:

"Deep" applications of the theory go beyond a reflexive invocation of the categorical scheme and ultimately bring about a different way of thinking about children and their education (Gardner, 1995, p. 16) 
In other words, placing students in categories is not the essence of the TMI. What is the essence is realising that all children are different and have likes and dislikes when it comes to teaching and learning and this creates challenges for lecturers and teachers.

\section{Conclusion}

So, to construct an answer to the title of this article: Is the Multiple Intelligences Theory a Research-Based Theory or a Story with a Positive Message? There is enough critical evidence from researchers at this point in time to question whether the Multiple Intelligences Theory has a solid research-based although it does resonate with a number of results that have arisen from other rigorous research studies such as the evidence uncovered the theory that intelligence can reveal itself in different ways (Shearer, \& Karanian, 2017).

However, for all teachers and lecturers, it is a story with a very positive message about classroom teaching and about their students. Students come to class with their individual strengths and weaknesses and the challenge for teachers and lecturers is to cater for all the individual needs of their students. This challenge goes to the heart of pedagogy, to the variety of experiences and strategies that teachers use within their classrooms. In the teachers' lesson plans are group work and collaborative learning ever used? Are illustrations, graphs, diagrams, films, or videos regularly used? Are music, radio and recordings ever used in the teaching of mathematics? Are discussions a regular part of lessons? Do mathematics classrooms ever have brief 'mathletics' breaks where the class participates in a 'mathsrobics' session that involves some body movement and stretching? What strategies are being used to differentiate teaching, differentiate learning and differentiate assessment?

Thus, for all educators the TMI issues a challenge which is to provide all their students with a learning environment containing the richest variety of strategies to cater for all the different types of 'intelligences' in a way that improves not only the students' strengths but also improves their weaknesses. The more areas of the brain that the teaching 'lights up', the greater the learning and retention in the student's long-term memory.

To conclude this paper, it is only fitting to leave the final say to Professor Gardner himself:

From my perspective, the essence of the theory is respect for the many differences among people, the multiple variations in the ways that they learn, the several modes by which they can be assessed, and the almost infinite number of ways in which they can leave a mark on the world (Gardner, 2009, p.x). 


\section{References}

Allix, N. M. (2000). The theory of multiple intelligences: A case of missing cognitive matter. Australian Journal of Education, 44(3), 272- 293.

Armstrong, T. (2009). Multiple Intelligences in the classroom, $3^{\text {Rd }}$ Edition (pp. 1x-x). VA: Assn for Supervision \& Curriculum.

Basak, B., \& Bengi, B. (2013). Multiple Intelligence Theory for Gifted Education: Criticisms and Implications. Journal for the Education of the Young Scientist and Giftedness, 1(2), $1-12$

Boaler, J. (2016). Mathematical Mindsets. San Francisco CA: Jossey-Bass.

De, Bruyckere, P., Kirschner, P. A., \& Hulshof, C.D. (2015). Urban Myths about Learning and Education. New York: Academic Press.

Doidge, N. (2008). The brain that changes itself: Stories of personal triumph from the frontiers of brain science (Revised Edition). Melbourne: Scribe Publications Pty Ltd

Furnham, A. (2009). The Validity of a New, Self-report Measure of Multiple Intelligence. Current Psychology, 28(4), 225-239. doi: 10.1007/s12144-009-9064-z.

Gardner, H. (1983/1993a) Frames of Mind: The Theory of Multiple Intelligences. New York: Basic Books.

Gardner, H. (1993b). The multiple intelligences: The theory in practice. New York: Basic Books.

Gardner, H. (1995). "Multiple intelligences" as a catalyst. English Journal, 84(8), 16-18.

Gardner, H. (1998). A multiplicity of intelligences. Scientific American, 9(4), 18-23.

Gardner, H. (2009). Preface, In T. Armstrong, Multiple Intelligences in the classroom, $3^{\text {Rd }}$ Edition (pp. 1x-x). VA: Assn for Supervision \& Curriculum.

Gardner, H., \& Moran, S. (2010). The Science of Multiple Intelligences Theory: A Response to Lynn Waterhouse. Educational Psychologist, 41(4), 227-232.

Klein, P. D. (1997). Cognitive Processes; Curriculum Development; Educational Planning; Intelligence; Multiple Intelligences; Teaching Methods; Theories; Gardner (Howard). Canadian Journal of Education, 22(4), 377-94.

Klein, P. D. (1998). A Response to Howard Gardner: Falsifiability, Empirical Evidence, and Pedagogical Usefulness in Educational Psychologies. Canadian Journal of Education 23(1): 103-112.

Matthews, D. (1995) Gardner's multiple intelligence theory: An evaluation of relevant research literature and a consideration ofits application to gifted education. In R. Fogarty \& J. Bellanca (Eds.), Multiple intelligences: A collection. Highett, Vic.: Hawker Brownlow Education, Australia.

McEwan-Adkins, E. (2012). Emphasizing learning styles based on hunches. Illinois Loop, Retrieved November 10, 2019, from: http://www.illinoisloop.org/mcewan_hunches.html

Morgan, H. (1996). An analysis of Gardner's theory of multiple intelligence. Roeper Review, $18(4), 263-269$ 
Schulte, M. J., Ree, M. J., \& Carretta, T. R. (2004). Emotional intelligence: not much more than $\mathrm{g}$ and personality. Personality and Individual Differences, 37(5), 1059-1068. doi: http://dx.doi.org/10.1016/j.paid.2003.11.014.

Shearer, C.B., \& Karanian, J.M. (2017). The neuroscience of intelligence: Empirical support for the theory of multiple intelligences? Trends in Neuroscience and Education 6, 211223.

Stahl, S. A. (1999). Different strokes for different folks? American Educator. Retrieved November 1, 2019, from: https://www.aft.org/sites/default/files/periodicals/DiffStrokes.pdf

Visser, B. A., Ashton, M. C., \& Vernon, P. A. (2006a). Beyond g: Putting multiple intelligences theory to the test. Intelligence, 34(5), 487-502. doi: http://dx.doi.org/10.1016/j.intell.2006.02.004.

Visser, B. A., Ashton, M. C., \& Vernon, P. A. (2006b). g and the measurement of Multiple Intelligences: A response to Gardner. Intelligence 34, 507-510

Waterhouse, L. (2006a). Inadequate Evidence for Multiple Intelligences, Mozart Effect, and Emotional Intelligence Theories. Educational Psychologist, 41(4), 247-255. doi: 10.1207/s15326985ep4104_5.

Waterhouse, L. (2006b). Multiple Intelligences, the Mozart Effect, and Emotional Intelligence: A Critical Review. Educational Psychologist, 41(4), 207-225. doi: 10.1207/s15326985ep4104_1.

White, J. (2004, November 12). Unpick Wooly Thinking: The modish Multiple Intelligence bandwagon is run on flaky, flawed psychology. Times Educational Supplement, Opinion, Issue 4609, 23. 
Theory Editor's Note: Is the Multiple Intelligences Theory

a Research-Based Theory or a Story with a Positive Message? 